\title{
A New Degradative Pathway for Heparan Sulfate Proteoglycan
}

\author{
ヘパラン硫酸プロテオグリカンの新しい分解経路
}

\author{
Key Words : degradation, heparan sulfate, heparin, nitric oxide
}

Vascular endothelial cells produce nitric oxide (NO) which can diffuse to neighbouring smooth muscle cells and initiate relaxation and vasodilation. NO is generated from arginine in a reaction catalyzed by NO-synthase and has a short lifetime. NO is also produced by neuronal cells, and is involved in neural transmission. Large quantities of $\mathrm{NO}$, as well as superoxide, are produced by neutrophils and monocytes on inflammatory stimulation, such as lipopolysaccharide. Superoxide combines with NO to make peroxynitrite, a very powerful nonspecific degradative agent with hydroxyl radical-like properties.

Heparan sulfate (HS) and heparin are members of the glycosaminoglycan group of complex polysaccharides. They normally present as a proteoglycan (PG) in which several HS or heparin chains are covalently attached to a core protein. In intact tissue heparin is confined to mast cells, where it is stored in cytoplasmic granules, while HS is ubiquitously distributed on the cell surface and in the extracellular matrix. They possess a complex polymeric structure which consist of a disaccharide repeat of glucosamine and hexuronic acid (iduronic or glucuronic acid). They are highly sulfated, and heterogeneous in size, charge and biological activities.

One of the decomposition-products of NO is nitrous acid $\left(\mathrm{HNO}_{2}\right)$. It has been known a long time that $\mathrm{HNO}_{2}$ can degrade $\mathrm{HS}$ and heparin. At $\mathrm{pH}$ values around 4, there is preferential cleavage of the hexosaminidic bond involving glucosamine residue with unsubstituted amino group, whereas bonds involving $\mathrm{N}$-sulfated glucosamine are sensitive at lower $\mathrm{pH}$. Vilar $e t$ $a l$. recently reported that the degradation of heparin by both endogenous and exogenous NO [Vilar, R.E., Ghael, D., Li, M., Bhagat, D.D., Arrigo, L.M., Cowman, M.K., Dweck, H.S., and Rosenfeld, L., (1997) Biochem. J. 324, 473-479].

The authors showed that degradation of exogenous heparin by endothelial cells is inhibited by NO synthase inhibitors, such as L-NNA ( $N$-nitro-L-arginine) and L-NMMA ( $N$ monomethyl-L-arginine). In addition, exogenous NO gas can initiate degradation of heparin and HS in neutral as well as acidic, aqueous solutions. On the other hand, hyaluronan was found to be resistant to degradation by NO gas and by the cells, but was susceptible to degradation by peroxynitrite, a metabolic product of the reaction of NO with superoxide. However, peroxynitrite did not degrade heparin and HS. Thus, endothelial cell-derived NO is capable of degrading heparin and $\mathrm{HS}$ via $\mathrm{HNO}_{2}$ rather than peroxynitrite.
血管内皮細胞は隣接した平滑筋細胞に拡散し、血管弛緩や 拡張を引き起こす酸化窒素(NO) を生成する。この NOはNO合 成酵素によりアルギニンから生成され、半減期は短い。NOは また、神経細胞によっても生成され、神経伝達にも関与してい る。超酸化物とともに多量の NOが、リポ多糖のような炎症性 の刺激で好中球や単球により生成される。超酸化物はNO と反 応して過酸化窒素となり、強力な非特異的分解能を示す酸化水 素ラジカルのような特徵をもつようになる。

ヘパラン硫酸 (HS) やへパリンは複合糖質の中でグリコサ ミノグリカングループに属しており、通常は一つのコアタンパ ク質に複数の HS あるいはへパリン糖鎖が共有結合したプロテ オグリカンとして存在している。正常組織では、ヘパリンは肥 満細胞のみに存在し、細胞内分泌顆粒に蓄積されている。他方、 HSは細胞表面や細胞外マトリックスに広く分布している。これ らの分子はグルコサミンとへキサウロン酸(イズロン酸或いは グルクロン酸) の二糖体の繰り返し構造からなる複雑な多糖構 造をしており、硫酸化度、サイズ、電荷、生物学的活性におい て多様性を有している。

$\mathrm{NO}$ の分解物の一つは亜硝酸 $\left(\mathrm{HNO}_{2}\right)$ である。 $\mathrm{HNO}_{2}$ が $\mathrm{HS}$ や ヘパリンを分解することは長い間知られていた。およそ4の $\mathrm{pH}$ で、非置換アミノ基をもつグルコサミン残基を含んだへキサア ミン結合を特異的に分解する。一方、 $N$-硫酸化グルコサミンを 含んだ結合はより低い $\mathrm{pH}$ で分解される。ビラーらは最近、へ パリンは内因性そして外因性のNOにより分解されることを報 告した[Vilar, R.E., Ghael, D., Li, M., Bhagat, D.D., Arrigo, L.M., Cowman, M.K., Dweck, H.S., and Rosenfeld, L., (1997)Biochem. J. 324, 473-479].

その著者らは、内皮細胞による外因性へパリンの分解は、 L-NNA(N-ニトロ-L-アルギニン)やL-NMMA(N-モノメチル-Lアルギニン)のような $\mathrm{NO}$ 合成酵素阻害片によって抑制される ことを示した。さらに、外因性NOガスはへパリンやHSの分解 を酸性水溶液のみならず中性水溶液下でも引き起こすことがで きる。他方、ヒアルロナンは、NO ガスや細胞により分解され ることはないが、NO と超酸化物との代謝生成物質である過酸 化窒素により分解を受ける。しかし、過酸化窒素はへパリンや HS を分解しない。このように、内皮細胞由来のNOはヘパリン や $\mathrm{HS}$ を過酸化窒素ではなく $\mathrm{HNO}_{2}$ の生成によって分解するこ とができる。 
Turnover of extracellular matrix HSPGs occurs by two basic routes; by endocytosis and by shedding into the medium. The internalized HSPG is rapidly processed to free HS chains by protease cleavage of the core protein and/or heparanase (endo- $\beta$-glucuronidase) cleavage of HS chains. The HS chains are progressively converted to smaller oligosaccharides in the pre-lysosomal metabolism. Ultimately, most of the oligosaccharides enter the lysosomes, where they are converted to monosaccharides and free sulfate. On the other hand, mechanisms involved in shedding of HSPG into the medium and their regulation have not been elucidated in detail. The discovery introduced in this topics that NO gas degrades HS and heparin of extracellular matrix may at least in a part explain the mechanism. Since NO is constitutively produced by endothelial cells, this degradation of HS may be part of its normal turnover.

Heparin and HS interact with numerous proteins, including extracellular matrix proteins, growth factors, chemokines, and enzymes such as extracellular superoxide dismutase; thus NO, by degrading extracellular matrix HSPG, may control the release of these regulatory factors. Macrophages and neutrophils release large amounts of NO and superoxide, forming peroxynitrite, which may result in increased degradation of hyaluronan, but not HSPG. Degradation or altered synthesis of hyaluronan of joint synovial fluid has been linked to rheumatoid arthritis. The balance between NO and superoxide may determine which glycosaminoglycan component of the extracellular matrix is destroyed and may be important in regulating disease processes. Thus, NO and superoxide may be involved in the regulation and pathology of extracellular matrix metabolism.

\section{Reported by Ishihara, $M$.}

National Defense Medical College

Research Institute

Tokorozawa, Saitama 359-8513, Japan

FAX:81-429-91-1611
細胞外マトリックス HSPG の代謝は、エンドサイトーシス と培地中への放出という二つの基礎的経路によって起こる。細 胞内に取り込まれたHSPG は、すみやかにタンパク分解酵素に よるコアタンパク質の分解やへパラナーゼ(エンド- $\beta$-グルク ロニダーゼ)によるHS鎖の分解によりリソゾーム前代謝として 遊離HS鎖にプロセスされ、さらに進んでより小さなオリゴ糖へ と分解されていく。最終的にこれらオリゴ糖鎖のほとんどはリ ソゾームに入り、そこで単糖や硫酸基に分解される。他方、培 地中に放出されるメカニズムやその制御については詳しく研究 されていない。このトピックスで紹介した NOガスが細胞外マ トリックスのHSやヘパリンを分解するという発見により、この メカニズムを少なくとも部分的には説明できるかもしれない。 NOは内皮細胞により生成されているのだから、HSのこの分解 は、HS の正常代謝経路の一部である可能性が強い。

ヘパリンやHS は細胞外マトリックスタンパク質、増殖因 子、ケモカイン、細胞外スーパーオキサイドジスムターゼのよ うな酵素等多くのタンパク質と相互作用する。すなわち、NOは 細胞外マトリックス HSPG を分解することによりこれら機能分 子の遊離を制御していると言える。マクロファージや好中球は 多量の NO や超酸化物を放出し、過酸化窒素を生成する。これ は、HSPGでなくヒアルロナンの分解を増加させる結果となる。 関節骨液中のヒアルロナンの分解や合成の変化は、慢性関節リ ウマチと相関していることが知られている。NOと超酸化物との バランスが細胞外マトリックス中のどのグリコサミノグリカン を分解するかを決定し、いろいろな病態進行を制御する重要な 要因であるもしれない。このように、NOや超酸化物が細胞外マ トリックス代謝の制御と病理に関係していると言うことができ る。

防衛医科大学校・研究センター・医療工学部門 石原 雅之 